\title{
Determination of VVER-1000 Thermal Power Based on Background Signals of Self- Powered Neutron Detectors
}

- Borysenko V., Dr. Tech. Sciences Institute for Safety Problems of Nuclear Power Plants, NAS of Ukraine, Kyiv, Ukraine ORCID: https://orcid.org/0000-0002-3035-0760

- Budyk D.

Private Joint-Stock Company «Severodonetsk Research and Production Association «lmpulse», Severodonetsk, Ukraine ORCID: https://orcid.org/0000-0002-3396-5832

- Goranchuk V., PhD Institute for Safety Problems of Nuclear Power Plants, NAS of Ukraine, Kyiv, Ukraine ORCID: https://orcid.org/0000-0002-1505-2749

The value of the reactor thermal power (RTP) is used in the VVER-1000 control systems in most algorithms for generation of control, blocking and protection signals. Besides, the technical and economic indicators of the power unit are determined by this parameter. Plans to increase VVER-1000 RTP to $101.5 \%$, and later to $104-107 \%$ of the nominal require additional justification of the accuracy of the RTP determination. Therefore, the task of increasing the accuracy of RTP determination is important. The paper describes the ways to improve the accuracy of weighted mean thermal power (WMTP) determination by selecting the optimal weight coefficient (that subsequently is used for WMTP determination) of each of the methods of RTP determination, namely: by thermotechnical parameters of the primary and secondary sides by neutron flux in the in-core monitoring system (ICMS) and in the neutron flux control equipment (NFCE). Another possibility of increasing the accuracy of WMTP determination, namely by increasing the number of methods of RTP determination, is also considered in the paper. The analysis of changes in the background signals of self-powered neutron detectors (SPNDs) during the VVER-1000 fuel campaigns shows the fundamental possibility of using the total background signal as a separate and independent method for RTP determination. The paper presents the results of the calculation of RTP determination error taking into account the coefficients of the components of the total RTP determination error: systematic, dynamic and random errors, which must be determined during the commissioning phase. The results of reduction of the error of WMTP determination in case of application of the additional method of RTP determination based on background signals of the SPNDs are presented. Theoretically, possible minimum values of the WMTP determination error are given depending on the values of the error of the RTP determination by separate methods.

Ke y w o r d s: reactor thermal power, thermotechnical parameters, neutron flux parameters, self-powered neutron detector, background (compensation) cable, weight coefficients.

(c) Borysenko V., Budyk D., Goranchuk V., 2019 
The thermal power of the VVER-1000 reactor (RTP) is not directly measured, but is determined based on indirect RTP determination methods in the following ways [1]:

1) by parameters of the primary side;

2) by parameters of the secondary side - by parameters of steam and feedwater flow rate in the steam generator (SG);

3) by parameters of the secondary side - by parameters of steam and feedwater flow rate in the high pressure heater (HPH);

4) by signals of the neutron flux control equipment (NFCE);

5) by signals of self-powered neutron detectors (SPND).

The weighted mean thermal power of the reactor (WMTP) is determined based on RTP values determined by different methods.

The value of WMTP $N_{\text {mean }}$ and the error of its determination $\delta N_{\text {mean }}$ are calculated taking into account the weight coefficient $w_{i}$ of each method of RTP $N_{i}$ determination [5]:

$$
\begin{gathered}
N_{\text {mean }}=\frac{\sum_{i=1}^{N} w_{i} \cdot N_{i}}{\sum_{i=1}^{N} w_{i}}, \\
\delta N_{\text {mean }}=\frac{\sqrt{\sum_{i=1}^{N}\left(w_{i} \cdot \delta N_{i}\right)^{2}}}{\sum_{i=1}^{N} w_{i}},
\end{gathered}
$$

where $\delta N_{i}$ is the error of RTP determination by the i-th method.

The importance of the most accurate determination of the RTP and the WMTP follows from the fact that the control of the reactor power is carried out on the basis of the signals of the NFCE, which in turn is regularly calibrated by the values of the WMTP.

The NFCE generates signals for VVER-1000 control systems: automatic power controller (APC), power reducing/limiting device (PRLD). Besides, preventive protection (PP), accelerated unit unloading (AUU) and emergency protection (EP) are implemented based on important safety parameters: neutron reactor power, reactor period, and reactor reactivity.

Therefore, the task of increasing the accuracy of RTP determination is relevant especially when implementing plans to increase the power of VVER-1000 up to $104,107 \%$ of the nominal level $\left(N_{\text {nom }}\right)$.
RTP determination by parameters of the primary side

Let us consider the components of the error in RTP determination by parameters of the primary side.

RTP by parameters of the primary side for the i-th working loop $N_{1, i}$ is determined as follows:

$$
N_{1, i}=G_{i} \cdot\left(I_{i, h}-I_{i, g}\right), \mathrm{W}
$$

where $G_{i}$ — the coolant flow rate in the i-th loop, $\mathrm{kg} / \mathrm{s}$; $I_{i, h}, l_{i, g}$ - the coolant enthalpy in hot and cold legs of the i-th loop, respectively, J/kg.

In practice, the RTP by parameters of the primary side is determined on the basis of the measured parameters, and therefore the formula (3) takes the following form:

$$
N_{1, i}=G_{i}^{m} \cdot \rho_{i, g} \cdot\left(I_{i, h}-I_{i, g}\right) \cdot 10^{-6} / 3.6, \mathrm{MW}
$$

where $G_{i}^{m}$ - the coolant flow rate in the i-th loop, $\mathrm{m}^{3} / \mathrm{h}$;

$\rho_{i, g}$ - the coolant density in the cold leg of the i-th loop, $\mathrm{t} / \mathrm{m}^{3}$.

The coolant flow rate is determined by the head vs. flow rate characteristic (HFC) of the main circulation pump (MCP) in terms of the pressure drop at the MCP, which is measured by several sensors. The enthalpy and density of the coolant are determined by known empirical dependencies of water and water vapor parameters on the temperature and pressure of the coolant. Pressure and temperature in the cold and hot legs of each loop are measured by several sensors.

Thus, the absolute error of RTP determination by parameters of the primary side for the i-th loop can be defined as:

$\Delta\left(N_{1, i}\right)=N_{1, i} \sqrt{\left[\frac{\Delta\left(G_{i}^{m}\right)}{G_{i}^{m}}\right]^{2}+\left[\frac{\Delta\left(\rho_{i, g}\right)}{\rho_{i, g}}\right]^{2}+\frac{\left[\Delta\left(I_{i, h}\right)\right]^{2}+\left[\Delta\left(I_{i, g}\right)^{2}\right]}{\left[I_{i, h}-I_{i, g}\right]^{2}}}$

where $\Delta(X)$ - absolute error of determination of parameter $X$.

In turn, the absolute error of determination of each parameters of a formula (5) is determined by dependences of this parameter on the corresponding parameters and formulas. For example, 
$\Delta\left(G_{i}^{m}\right)$ is determined by the error of coolant flow rate determination by the HFC of the MCP, which in turn is determined by the error of the function, which approximates the factory dependence of the HFC, obtained at the plant where the MCP is manufactured.

The relative error of coolant density determination in the cold leg due to the modernization of ICMS, is $\sim 0.1 \%$, which is much less than the error of coolant flow rate determination $\sim(1-3) \%$. For example, error of coolant temperature determination in the primary side, which is used to determine the density of the coolant, was reduced due to: use of individual more high-accuracy analog-to-digital converter ( $A D C)$, increase of sampling frequency of sensors as well as use of individual calibrating characteristics of thermocouples (TC) and resistance thermometers (RT). Such measures allowed reducing absolute error in temperature determination from $\pm 1{ }^{\circ} \mathrm{C}$ to $\pm(0.1 \div 0.2){ }^{\circ} \mathrm{C}$ [2].

The error of enthalpy determination can reach (3-5) \% and is caused mainly by the error of temperature determination in hot legs, which is associated with the peculiarity of coolant hydrodynamics in hot legs of VVER-1000. This is primarily the phenomenon of the stratification of the coolant in the pipeline of hot leg, as well as the ability to take into account this effect on a particular VVER-1000 depending on the number of temperature sensors in the hot leg and their location.

Thus, the error in RTP determination by parameters of the primary side depends on:

error of determination of the coolant flow rate through the loop on the basis of the HFC of the MCP, which in turn is determined by the difference between the actual scheme of measurement of pressure difference on the MCP and the bench scheme at the MCP manufacturer; and accuracy of determination of the coolant temperature of the cold leg, from which the density of the coolant is determined;

error in determining the coolant enthalpy, which depends on the accuracy of determination of coolant pressure and temperature in the hot and cold legs.

The stratification of the coolant depends on the reactor power and the number of working loops, and is a feature of the each particular VVER-1000. Besides, each particular VVER-1000 has its own other special features - other processes that will influence the accuracy of the RTP determination by parameters of the primary side. First of all, this is a phenomenon of twisting of the coolant in the downcomer and reactor core. For example, twisting of the coolant in the downcomer of VVER-1000 can reach $90^{\circ}$ [4], which will significantly affect the error of determining the thermal power of a single loop due to the shift of the coolant to the adjacent sector of the core, and, accordingly, the coolant shift to the adjacent loop.

The error in RTP determination using other methods also depends on the reactor power and the number of working loops, and also is a feature of the each particular VVER-1000.

Next steps can be done to ensure the necessary accuracy of the RTP determination:

increasing the accuracy of each individual method of the RTP determination, by improving the accuracy class of the measuring equipment;

justification and implementation of additional methods of RTP determination in operational practice;

justification and selection of optimal weight coefficients $w_{i}$, which ensure minimization of error in WMTP determination $\delta N_{\text {mean }}$.

Let us confirm the veracity of this approach theoretically.

The error in determining the weighted mean value

Let's consider how the increase in the methods of RTP determination affects the error in WMTP determination.

It was shown in [5] that, under the assumption that the results of two measurements $x_{1}$ and $x_{2}$ satisfy the Gauss distribution and denote unknown true value of $x$, the best estimate of their weighted mean value is defined as:

$$
x_{\text {best }}=\frac{w_{1} \cdot x_{1}+w_{2} \cdot x_{2}}{w_{1}+w_{2}}
$$

where $w_{1}, w_{2}$ are weights of the first and second measurements in determining the $x_{\text {best }}$, respectively;

$$
w_{i}=\frac{1}{\sigma_{i}^{2}},
$$

$\sigma_{i}$ - the error of the $i$-th measurement. 
This method also can be used to determine the weighted mean value in the case of an arbitrary number of measurements:

$$
x_{\text {best }}=\frac{\sum_{i=1}^{N} w_{i} \cdot x_{i}}{\sum_{i=1}^{N} w_{i}}
$$

where $N$ is the number of measurements, in our case, the number of methods for WMTP determination.

The error in determining the best estimate of the weighted mean value of $N$ measurements is defined as:

$$
\sigma_{x_{\text {best }}}=\left(\sum_{i=1}^{N} w_{i}\right)^{-\frac{1}{2}},
$$

The best estimate of the WMTP is determined taking into account the weight of each of the methods of RTP determination, and the weight is determined in accordance with (7).

The analysis of equation (9) leads to the following important conclusions:

with the increase in number of the methods of RTP determination, the error of WMTP determination decreases;

the error in WMTP determination by $\mathrm{N}$ methods is not more than the error of the most accurate method of RTP determination.

Thus, it has been proven that in order to reduce the error in the WMTP determination, it is necessary to try to reduce the error in each method of RTP determination, as well as to introduce additional methods of RTP determination.

It is necessary to take into account that the error of RTP determination by each of the methods for a particular VVER-1000 depends on the mode of its operation, and therefore the weight of each of the methods of RTP determination depends on the mode of operation of a particular VVER-1000.

\section{Additional methods of RTP determination}

Let us consider additional methods of RTP determination that can be applied at VVER-1000.

One of the additional methods for RTP determination may be the so-called radiation method, based on measurement of the induced activity of the coolant of the primary side. It was shown in research [6], [7], that the so-called nitrogen $\left({ }^{16} \mathrm{~N}\right.$ isotope) activity of the coolant of the primary side is proportional to the neutron flux density in the reactor, and, accordingly, to the RTP.

The possibility of monitoring the RTP based on ${ }^{16} \mathrm{~N}$ sensors has also been confirmed at operating nuclear power plants. For example, 2 serial power units (1990 and 1993 of commissioning) at NPP Comanche Peak (USA) with PWR capacity of $1150 \mathrm{MW}$ are equipped with standard control systems of RTP on the basis of ${ }^{16} \mathrm{~N}$ sensors [8], besides there are other positive examples [9]. Such a system has high dynamic characteristics, for example, it is noted in [10] that determined by the ${ }^{16} \mathrm{~N}$ sensors RTP gives the most accurate estimation in the operation transients.

Since 1986, studies have been being conducted at the Kalinin NPP to determine the VVER-1000 RTP based on ${ }^{16} \mathrm{~N}$ sensors [11]. The principle possibility of determining RTP according to the ${ }^{16} \mathrm{~N}$ sensors of the system of correlation determination of the coolant flow rate in the primary side of VVER-1000 has been confirmed. However, the actual error in determining the coolant flow rate by leg is $\sim 4 \%$, which is still greater than that achieved on similar systems at foreign NPPs, namely $1.5 \%$ [9], [12].

After solving the problem, with the so-called «stream effect» effect [13], and ensuring the necessary accuracy in determining the temperature at the exit of the fuel assemblies, it will be possible to use the determination of the RTP by the power of fuel assemblies equipped with thermal control. It is possible to provide the necessary accuracy of determining the RTP using the ability to determine the velocity of the coolant in various sectors of the VVER-1000 core by means of the in-core noise diagnostic system [14].

One shall consider a method for determining RTP based on the background signals of the SPNDs that belong to ICMS. The SPND current is formed by the following main components:

the first component is the current, which occurs as a result of activation of a rhodium emitter of SPND by reactor core neutrons, and consequent $\beta$-decay of nuclei of rhodium emitter;

the second component is the current that occurs in the SPND circuit (communication line) under the action of $\gamma$-ray of the reactor core;

the additional component is the current that occurs in the SPND due to the generation of $\beta$ particles 
in the detector materials under the influence of reactor $\gamma$-rays (usually the share of this current does not exceed $10 \%$ of the current of the SPND).

The reactor power is proportional to the neutron flux density in the reactor. Therefore, the SPND signal, which is formed under the influence of the neutron flux, is also proportional to the RTP. In order to extract the SPND signal, which is proportional only to the neutron flux, separation of the SPND signal and the signal, which is formed in the SPND circuit is performed at the hardware level in the ICMS.

In practice, this is realized by laying additional, so-called, background (compensation) cable in the neutron flux measuring channel (NFMC) of the ICMS, which is identical to the SPND communication line both in materials and in length. Each SPND has its own background cable. Previously, the NFMC had one background cable with the length equal to the length of the communication line of the lowest SPND in the NFMC. For the other SPNDs, the background signal was calculated depending on the length of the communication line of the particular SPND in the reactor core [1].

Thus, the background signal is proportional to the intensity of $\mathrm{Y}$-radiation of the reactor core, which in turn is proportional to the RTP. Systems of reactor power control with the use of $\gamma$-calorimeters are based on this principle [15].

In practice, control systems that determine the power of a reactor based on signals from neutron detectors are more widely used. First, this is due to the fact that it is the neutron flux density that determines the RTP. The $\gamma$-detector signal is also proportional to the reactor power, but this proportionality is more complex than for a neutron detector. The reason is that the fission fragments that occur during the fission chain reaction of the fuel nuclei contribute to RTP the so-called residual thermal power, which is mainly determined by the intensity of $\beta$ - and $\gamma$-radiation of the fission fragments. The intensity of the residual thermal power reaches $\sim 6.6 \%$ of the reactor power during its long-term operation. About half of this residual thermal power is determined by the $\gamma$-radiation of fission fragments. To correctly take into account the contribution from the residual energy release of $\mathrm{\gamma}$-radiation to the $\mathrm{\gamma}$-detector signal, when calculating the RTP, it is necessary to constantly take into account: the power on which the reactor operates, the time elapsed since the beginning of the reactor operation, the fuel composition and history of fuel operation (except first campaign fuel), and other parameters.

It should also be noted that the signal of neutron detectors, in contrast to the signal of $\gamma$-detectors, is more localized. For example, it was shown in [16] that $\sim 70 \%$ of SPND signal is formed by neutrons generated directly in the fuel assembly in which the SPND is located, and $30 \%$ of SPND signal is determined by neutrons of adjacent fuel assemblies. In addition, the signal of the $\gamma$-detector is formed by $Y$-ray photons, which fly into the detector from a greater distance. Therefore, another advantage of neutron detectors over $\mathrm{\gamma}$-detectors is their larger localization, which is especially important for the control of energy-intensive cores, which includes the VVER-1000 core.

RTP determination based on the background signals of the SPNDs

Let us consider how the signal that is transmitted by the background (compensation) cable of the SPND changes during the VVER-1000 fuel campaign and also investigate the possibility of using,

Fig. 1 - Changes in WMTP $(\mathrm{N}, \mathrm{MW})$ during the 27-th fuel campaign, and deviations of $\mathrm{N}_{\mathrm{SPND}}$ and $\mathrm{N}_{\mathrm{F}}$ powers from WMTP (\%).

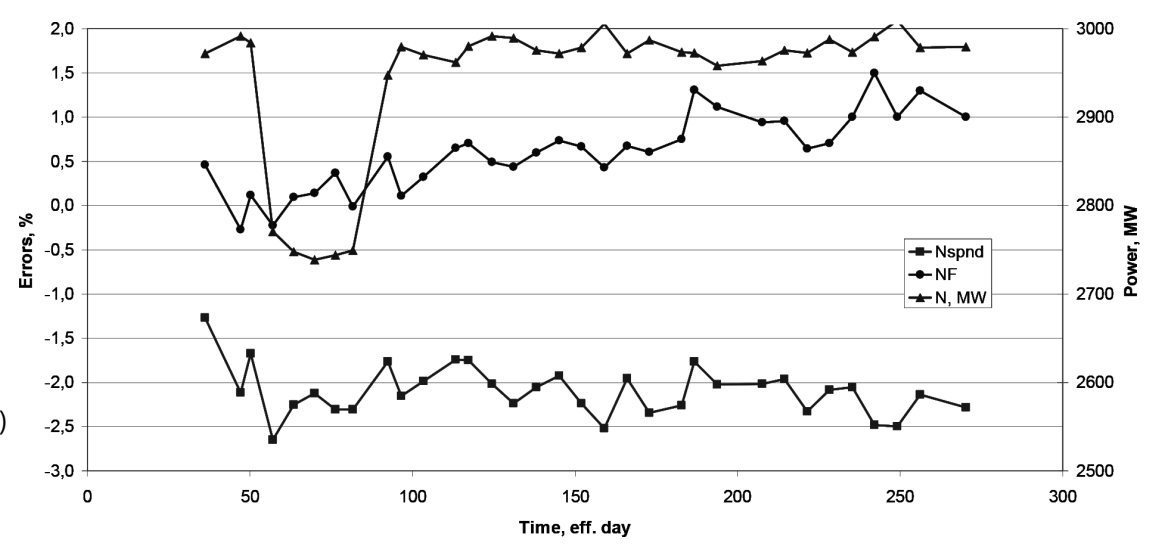




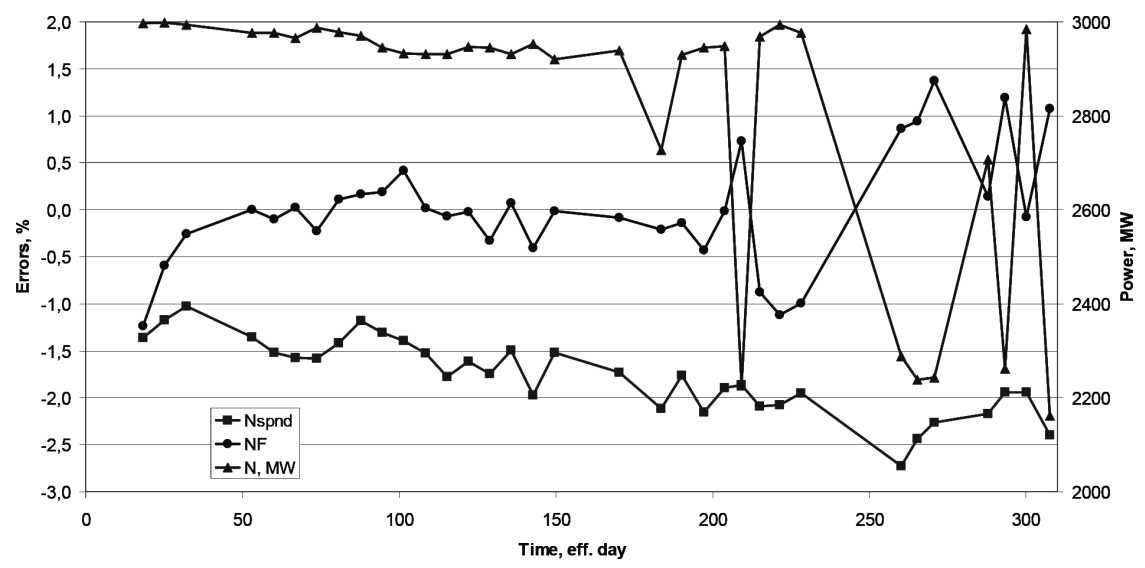

Fig. 2 - Changes in WMTP (N, MW) during the 28-th fuel campaign, and deviations of $\mathrm{N}_{\text {SPND }}$ and $\mathrm{N}_{\mathrm{F}}$ powers from WMTP (\%).

as an additional method, the RTP determination based on the background signals of the SPNDs $\left(\mathrm{N}_{\mathrm{F}}\right)$.

Figures 1, 2 show the data on the changes in the WMTP during the 27-th and 28-th fuel campaigns of the VVER-1000, as well as the deviations of $\mathrm{N}_{\text {SPND }}$ and $\mathrm{N}_{\mathrm{F}}$ powers (obtained by SPND signals and background signals of the SPNDs, respectively) from WMTP.

An analysis of the obtained data allows concluding that it is possible to use the $\mathrm{N}_{\mathrm{F}}$ signal for RTP determination: for operating modes at steady-state power levels with an error of no more than $1.5 \%$, and when the power changes by more than $10 \%-$ with an error of no more than $2.0 \%$.

Thus, the method for RTP determination by $N_{F}$ can be recommended as an additional one when determining the WMTP. Taking into account the estimated errors of the RTP determination based on $N_{F}$ signals, as well as the conclusions from the analysis of formula (9) (that the error in WMTP determination decreases with a decrease in the error in RTP determination by a individual method, as well as with an increase in the number of methods of WMTP determination), we can expect a decrease in the error in WMTP determination provided that the method for RTP determination based on $N_{F}$ signals is included in the algorithm for WMTP determination.

\section{Minimization of the error of WMTP determination}

Let us estimate the error of WMTP determination based on traditional algorithm with the use of five methods, as well as based on algorithm with the inclusion of the additional method of RTP determination on the basis of $N_{F}$ signals.
For this purpose, values of the relative error $\delta_{i}$ of RTP determination in VVER-1000 by different methods are used according to [17]. As it has already been noted, the errors of RTP determination depend on many factors and they should be determined separately for each VVER-1000 and depending on the mode of operation of reactor plant (RP). However, for a long time, the weight coefficients $w_{i}$ were not taken into account in the calculation of the WMTP in the ICMS [18].

Table 1 — Errors of VVER-1000 RTP determination [17].

\begin{tabular}{|c|c|c|c|c|c|c|}
\hline $\begin{array}{c}\text { Method of RTP } \\
\text { determination }\end{array}$ & $\mathbf{N}_{\mathbf{1 k}}$ & $\mathbf{N}_{\text {SG }}$ & $\mathbf{N}_{\text {HP }}$ & $\mathbf{N}_{\text {SPND }}$ & $\mathbf{N}_{\mathbf{I C}}$ & $\mathbf{N}_{\mathbf{F}}$ \\
\hline$\delta_{\mathrm{i}} \%$ & 5.1 & 1.1 & 1.5 & 4.5 & 2.9 & 2.0 \\
\hline
\end{tabular}

Table 2 shows data on the weight coefficients of traditional methods of RTP determination, as well as the results of calculation of the WMTP error for various VVER-1000 power units and for various fuel campaigns when applying five and six methods of RTP determination (the 6-th method of RTP determination is based on $\mathrm{N}_{\mathrm{F}}$ signal). Error of the RTP determination by a separate method was taken according to Table 1, in order to carry out such estimation.

The paper [17] considers the technique for determining the weight coefficients of each of the methods of RTP determination that subsequently are used for WMTP determination. In order to apply the proposed technique, it is additionally necessary to determine the corresponding coefficients of the components of the total RTP determination error at the stages of commissioning works: $k_{1}$ - systematic error, $k_{2}-$ dynamic error, $k_{3}=1$ - random error.

Table 3 shows: the values of the weight coefficients $w_{i}$ of five methods of RTP determination, 
Determination of VVER-1000 Thermal Power Based on Background Signals of Self-Powered Neutron Detectors

Table 2 - Weight coefficients $w_{i}$ and relative error $\delta$ for VVER-1000 WMTP determination [17].

\begin{tabular}{|c|c|c|c|c|c|c|c|c|c|c|c|c|}
\hline & \multicolumn{3}{|c|}{ K5(13-22)* } & \multicolumn{4}{|c|}{ K6(12-20) } & \multicolumn{3}{|c|}{$\mathrm{T} 1(1-9)$} & T2 (1-7) & Kh1 (27-28) \\
\hline$w_{1 \mathrm{k}}$ & 0.250 & 0.200 & 0.164 & 0.250 & 0.200 & 0.281 & 0.076 & 0.231 & 0.267 & 0.177 & 0.173 & 0.157 \\
\hline$w_{S G}$ & 0.250 & 0.200 & 0.249 & 0.250 & 0.200 & 0.281 & 0.237 & 0.254 & 0.293 & 0.281 & 0.271 & 0.313 \\
\hline$w_{\mathrm{HP}}$ & 0.250 & 0.200 & 0.249 & 0.250 & 0.200 & 0.157 & 0.237 & 0.000 & 0.000 & 0.000 & 0.000 & 0.149 \\
\hline$w_{\text {SPND }}$ & 0.000 & 0.200 & 0.090 & 0.000 & 0.200 & 0.000 & 0.213 & 0.135 & 0.000 & 0.118 & 0.127 & 0.036 \\
\hline$w_{1 C}$ & 0.000 & 0.000 & 0.000 & 0.000 & 0.000 & 0.000 & 0.000 & 0.127 & 0.147 & 0.143 & 0.157 & 0.031 \\
\hline$w_{F}$ & 0.250 & 0.200 & 0.249 & 0.250 & 0.200 & 0.281 & 0.237 & 0.254 & 0.293 & 0.281 & 0.271 & 0.313 \\
\hline$\delta(5), \%$ & 1.81 & 1.76 & 1.38 & 1.81 & 1.76 & 2.06 & 1.47 & 1.88 & 2.07 & 1.62 & 1.63 & 1.34 \\
\hline$\delta(6), \%$ & 1.36 & 1.41 & 1.04 & 1.36 & 1.41 & 1.48 & 1.12 & 1.40 & 1.46 & 1.17 & 1.19 & 0.92 \\
\hline$\delta_{1}, \%$ & 0.45 & 0.35 & 0.34 & 0.45 & 0.35 & 0.58 & 0.35 & 0.48 & 0.61 & 0.46 & 0.44 & 0.42 \\
\hline
\end{tabular}

* In Table $2 \mathrm{An}\left(\mathrm{m}_{1}-\mathrm{m}_{2}\right)$ denotes:

A - name of NPP (K - Kozloduy NPP, T - Tianwan NPP, Kh - Khmelnitsky NPP);

$\mathrm{n}$ - unit number; $\mathrm{m}_{1}, \mathrm{~m}_{2}$ - fuel campaign numbers;

$\delta(5), \delta(6)$, - the relative errors in WMTP determination using 5 and 6 methods of RTP determination, respectively; $\delta_{1}=\delta(5)-\delta(6)$.

Table 3 - Weight coefficients $w_{i}$ depending on the different components of total error.

\begin{tabular}{|c|c|c|c|c|c|c|c|c|c|c|c|}
\hline Param. & \multicolumn{4}{|c|}{ T1 } & \multicolumn{3}{c|}{ T2 } & \multicolumn{3}{c|}{ KIn3 } \\
\hline $\boldsymbol{k}_{\mathbf{1}}, \boldsymbol{k}_{\mathbf{2}}$ & $\mathbf{0}$ & $\boldsymbol{k}_{\mathbf{2}}=\mathbf{0}$ & $\boldsymbol{k}_{\mathbf{2}}=\mathbf{1}$ & $\boldsymbol{k}_{\mathbf{2}}=\mathbf{0 . 5}$ & $\mathbf{0}$ & $\boldsymbol{k}_{\mathbf{2}}=\mathbf{0}$ & $\boldsymbol{k}_{\mathbf{2}}=\mathbf{1}$ & $\boldsymbol{k}_{\mathbf{2}}=\mathbf{0 . 5}$ & $\mathbf{0}$ & $\boldsymbol{k}_{\mathbf{2}}=\mathbf{0}$ & $\boldsymbol{k}_{\mathbf{2}}=\mathbf{1}$ \\
\hline$w_{1 \mathrm{k}}$ & 0.188 & 0.232 & 0.256 & 0.217 & 0.172 & 0.217 & 0.196 & 0.167 & 0.191 & 0.363 & 0.330 \\
\hline$w_{\mathrm{SG}}$ & 0.522 & 0.443 & 0.231 & 0.323 & 0.558 & 0.480 & 0.363 & 0.433 & 0.472 & 0.140 & 0.128 \\
\hline$w_{\mathrm{SPND}}$ & 0.053 & 0.068 & 0.150 & 0.128 & 0.030 & 0.039 & 0.079 & 0.068 & 0.033 & 0.065 & 0.074 \\
\hline$w_{\mathrm{IC}}$ & 0.070 & 0.090 & 0.197 & 0.167 & 0.074 & 0.098 & 0.196 & 0.167 & 0.138 & 0.266 & 0.301 \\
\hline$w_{\mathrm{F}}$ & 0.167 & 0.167 & 0.167 & 0.167 & 0.167 & 0.167 & 0.167 & 0.167 & 0.167 & 0.167 & 0.167 \\
\hline$\delta(4), \%$ & 1.39 & 1.61 & 1.92 & 1.66 & 1.32 & 1.52 & 1.52 & 1.35 & 1.42 & 2.44 & 2.32 \\
\hline$\delta(5), \%$ & 1.21 & 1.38 & 1.63 & 1.42 & 1.15 & 1.31 & 1.31 & 1.18 & 1.23 & 2.06 & 1.96 \\
\hline$\delta_{1}, \%$ & 0.19 & 0.23 & 0.28 & 0.24 & 0.17 & 0.21 & 0.21 & 0.18 & 0.19 & 0.38 & 0.36 \\
\hline
\end{tabular}

In Table 3 An denotes:

A - name of NPP (T - Tianwan NPP, Kln - Kalinin NPP);

$\mathrm{n}$ - unit number;

$\delta(4), \delta(5),-$ the relative errors in WMTP determination using 4 and 5 methods of RTP determination, respectively; $\delta_{1}=\delta(4)-\delta(5)$.

obtained with different combinations of accounting of total error components (systematic, dynamic and random errors); values of relative errors of WMTP determination obtained by using 4 and 5 methods of RTP determination with a corresponding normalization of $w_{i}$ to 1 . Table 3 shows only those values of $k_{1}, k_{2}$ that differ from 1 . The column with the number «0» contains $w_{i}$ values for the traditional method of error determination - without taking into account the coefficients $k_{1}, k_{2}, k_{3}$.

Method of RTP determination by the parameters of the secondary side (HPH) is not used at some 
Table 4 - The minimum possible values of the relative error $\delta_{\min }$ depending on $\delta_{\mathrm{i}}$.

\begin{tabular}{|c|c|c|c|c|c|c|c|}
\hline comb.\# & $\mathbf{1}$ & $\mathbf{2}$ & $\mathbf{3}$ & $\mathbf{4}$ & $\mathbf{5}$ & $\mathbf{6}$ & $\mathbf{7}$ \\
\hline$\delta N_{1 k}$ & 2.0 & 1.0 & 1.0 & 1.0 & 1.0 & 1.0 & 1.0 \\
\hline$\delta N_{S G}$ & 2.0 & 2.0 & 1.0 & 1.0 & 1.0 & 1.0 & 1.0 \\
\hline$\delta N_{H P}$ & 2.0 & 2.0 & 2.0 & 1.0 & 1.0 & 1.0 & 1.0 \\
\hline$\delta N_{S P N D}$ & 2.0 & 2.0 & 2.0 & 2.0 & 1.0 & 1.0 & 1.0 \\
\hline$\delta N_{I C}$ & 2.0 & 2.0 & 2.0 & 2.0 & 2.0 & 1.0 & 1.0 \\
\hline$\delta N_{F}$ & 2.0 & 2.0 & 2.0 & 2.0 & 2.0 & 2.0 & 1.0 \\
\hline$\delta_{\min }(1), \%$ & 2.00 & 1.00 & 1.00 & 1.00 & 1.00 & 1.00 & 1.00 \\
\hline$\delta_{\min }(2), \%$ & 1.41 & 0.89 & 0.71 & 0.71 & 0.71 & 0.71 & 0.71 \\
\hline$\delta_{\min }(3), \%$ & 1.15 & 0.82 & 0.67 & 0.58 & 0.58 & 0.58 & 0.58 \\
\hline$\delta_{\min }(4), \%$ & 1.00 & 0.76 & 0.63 & 0.55 & 0.50 & 0.50 & 0.50 \\
\hline$\delta_{\min }(5), \%$ & 0.89 & 0.71 & 0.60 & 0.53 & 0.49 & 0.45 & 0.45 \\
\hline$\delta_{\min }(6), \%$ & 0.82 & 0.67 & 0.58 & 0.52 & 0.47 & 0.44 & 0.41 \\
\hline
\end{tabular}

units with VVER-1000 (for example, Bushehr NPP, Tianwan NPP, Kalinin NPP) due to peculiarities in determination of corresponding thermal and technical parameters [2], [17]. Therefore, Table 3 does not show the values of weight coefficients of RTP determination method by parameters of the secondary side $(\mathrm{HPH})-w_{H P}$.

Tables 2 and 3 show the values of $\delta_{1}-$ a decrease in the relative error of WMTP determination when an additional method for RTP determination based on $N_{F}$ signals is included in the calculation of the NWTP, - for a wide range of applied values of the weight coefficients $w_{i}$. Thus, the use of an additional method of RTP determination based on $N_{F}$ signals to calculate the WMTP reduces the error of its determination by $0.2-0.5 \%$, which is a very important result, especially when carrying out work to justify the safety of VVER-1000 operation at high power levels.

Table 4 shows the minimum possible values of the relative errors $\delta_{\min }$ of the WMTP determination (number of methods of RTP determination ranges from 1 to 6 ) depending on the relative errors $\delta_{i}$ of the RTP determination of VVER-1000 by different methods in the case of optimal determination of the weight coefficients $w_{i}$ in accordance with (7). The results are presented only for two values of the relative error of each of the methods, namely $2.0 \%$ and $1.0 \%$.

\section{Conclusions}

The results of the $\delta 1$ estimation - decrease in the relative error of the WMTP determination when using the additional method of the RTP determination based on $N_{F}$ signals are presented; they allow recommending the use of the mentioned method of the RTP determination in the algorithm of the WMTP determination. It should be remembered that both the error of RTP determination in a separate method $\delta_{i}$, and weight coefficients $w_{i}$ are unique for a particular power unit with VVER-1000. The values of the weight coefficients $w_{i}$ are determined depending on the values of the relative error of RTP determination $\delta_{i}$, which in turn is determined on a particular VVER-1000 depending on the operating mode, reactor power, the number of operating loops, and also taking into account the results of studies at the stages of commissioning activities at the power unit.

\section{REFERENCES}

1. Bragin, V.A., Batenin, I.V., Golovanov, M.N., Kuzhil, A.S. et al. (1987). In-core monitoring systems of NPP with VVER. Energoatomizdat, Moscow, $128 \mathrm{p}$.

2. Dobrotvorskii, A.N. (2017). Development and substantiation of methods of determination of weighted mean power 
of NPP units with VVER-1000: The thesis for scientific degree of the candidate of technical sciences. Novovoronezh, $191 \mathrm{p}$.

3. Bai, V.F., Lupishko, A.N., Makarov, S.V., Bogachek, L.N. (2010). State of in-core thermal control and analysis of the main thermal and physical characteristics of RP of Kalinin NP. Book of abstracts, 7th International Scientific and Technical Conference «Safety, Effectiveness and Economics of Nuclear Power Engineering», Moscow, 228-230.

4. Bai, V.F., Bogachek, L.N., Makarov, S.V. (2015). Influence of HPH operating modes on temperature field at the inlet of fuel assembly in the core and on thermal and physical characteristics of VVER-1000 reactor of Kalinin NPP. Book of abstracts, 9th International Scientific and Technical Conference «Safety Assurance at NPP with VVER», Podolsk.

5. Taylor, J. (1997). An introduction to error analysis: the study of uncertainties in physical measurements. University Science Books, 2nd edition, 448.

6. Agapov, S.A., Lysenko, V.V., Musorin, A.I., Tsypin, S.G. (1991). Radiation methods for measuring VVER parameters. Energoizdat, Moscow, $129 \mathrm{p}$.

7. Lysenko, V.V., Musorin, A.I., Rymarenko, A.I., Tsypin, S.G. (1985). Determination of nuclear-physical and thermophysical characteristics of VVER using radiation meters. Energoizdat, Moscow (Rus).

8. Graham, K.F. (1977). $16 \mathrm{~N}$ Power measuring system. Rep WCAP-9191, Westinghouse Atomic Power Division, Pittsburgh, USA.

9. DÉCOR system (1997). Direct measurement of the reactor coolant flow based on cross-correlation of Nitrogen 16 time fluctuation. Research and development division EDF preprint, Chatou, France.

10. Comanche Peak Steam Electric Station Unit 2 (1996). Unidentified overpower condition following a substantial loss of feedwater heating. WANO inf. EAR ATL 96-012.

11. Kuz'min, V.V., Bogachek, L.N., Alyev, R.R. (2015). Correlation measurements of primary coolant flow rate by ${ }^{16} \mathrm{~N}$ activity at Kalinin NPP. Book of abstracts, 9th International Scientific and Technical Conference «Safety Assurance at NPP with VVER», Podolsk.

12. Technical report WCAP-13303 (1990), Westinghouse Atomic Power Division, Pittsburgh, USA.

13. Abdullaev, A.M., Kulish, G.V., Sleptsov, S.N., Zhukov, A.I. (2009). Influence of the guide thimble bypass flow on fuel assembly outlet temperature measurement in the VVER-1000 mixed core computational analysis. Book of abstracts, 6th International Scientific and Technical Conference «Safety Assurance at NPP with VVER», Podolsk (Rus).

14. Goranchuk, V.V. (2019). Monitoring of VVER-1000 core by methods of neutron-noise diagnostic: The thesis for scientific degree of the candidate of technical sciences. Kyiv, 190 p. (Ukr).

15. Karasev, V.S., Ogorodnik, S.S., Coglin, Yu.L. (1970). The study of the calibration characteristics of the calorimeter in intense fields of radiation. Nuclear Energy, 29(6), 449.

16. Borysenko, V.I., Piontkovskyi, Yu.F., Goranchuk, V.V. (2016). Model of formation of in-core neutron detector signal. Nuclear Physics and Atomic Energy, Kyiv, 17(4), 364-373.

17. Saunin, Yu.V., Dobrotvorskii, A.N., Semenikhin, A.V. (2008). Methods of estimation of weight coefficient when determining weighted mean thermal power of VVER reactors. Heavy Machine Building, Moscow, 11, pp. 13-17.

18. Vorobieva, D.V., Lipin, N.V., Milto, N.V., Milto, V.A., Sakharova, T.S., Skorokhodov, D.N. (2017). Calculation of RPpowerbased on signals from in-core detectors. Analysis of operation experience. Book of abstracts, 10th International Scientific and Technical Conference «Safety Assurance at NPP with VVER», Podolsk.
Визначення теплової потужності ВВЕР-1000 на основі сигналів фонових жил детекторів прямого заряду

\author{
В. І. Борисенко ${ }^{1}$, Д. В. Будик ${ }^{2}$, В. В. Горанчук ${ }^{1}$ \\ ${ }^{1}$ Інститут проблем безпеки АЕС НАН України, \\ м. Київ, Україна \\ 2 ПрАТ Сєверодонецьке науково-виробниче \\ об'єднання «Імпульс», м. Сєверодонецьк, Україна
}

Значення теплової потужності реактора (ТПР) використовується в системах контролю ВВЕР-1000 в більшості алгоритмів формування сигналів керування, блокування та захистів, а також за цим параметром визначаються техніко-економічні показники енергоблока. Плани з підвищення ТПР ВBEP-1000 до 101,5 \%, а пізніше і до 104-107 \% номінальної величини вимагають додаткових обґрунтувань щодо точності визначення ТПР. Тому задача підвищення точності визначення ТПР $\epsilon$ актуальною. В статті розглянуті способи підвищення точності визначення середньозваженої теплової потужності (СЗТП) реактора через вибір оптимальних значень вагових коефіцієнтів врахування кожного із способів розрахунку ТПР: за теплотехнічними параметрами 1-го та 2-го контурів, а також за параметрами нейтронного потоку в системі внутрішньореакторного контролю (СВРК) та в апаратурі контролю нейтронного потоку (АКНП). У статті розглянуто й іншу можливість підвищення точності визначення СЗТП реактора - через збільшення способів визначення ТПР. Проведений аналіз зміни сигналів фонових жил детекторів прямого заряду (ДПЗ) упродовж паливних кампаній ВВЕР-1000 показує принципову можливість використовувати сумарний сигнал фонових жил як окремий незалежний спосіб визначення ТПР. У статті наведено результати розрахунку похибки визначення ТПР з урахуванням коефіцієнтів складових загальної похибки: систематичної, динамічної та випадкової; які необхідно визначати на етапі пусконалагоджувальних робіт. Наведені результати зі зменшенням похибки визначення СЗТП реактора у разі застосування додаткового способу визначення ТПР на основі сигналів фонових жил ДПЗ. Наведено теоретично можливі мінімальні значення похибки визначення СЗТП при заданих значеннях похибок визначення ТПР окремими способами.

Ключові слова: теплова потужність реактора, теплотехнічні параметри, параметри нейтронного потоку, детектор прямого заряду, фонова жила, вагові коефіцієнти.

Отримано 29.08.2019 